\title{
Culture and identification of Desulfovibrio spp. from corals infected by black band disease on Dominican and Florida Keys reefs
}

\author{
S. Viehman ${ }^{1,3, *}$, D. K. Mills ${ }^{1}$, G. W. Meichel ${ }^{2}$, L. L. Richardson ${ }^{1}$ \\ ${ }^{1}$ Department of Biological Sciences and ${ }^{2}$ Southeast Environmental Research Center, Florida International University, \\ University Park, Miami, Florida 33199, USA \\ ${ }^{3}$ Present address: NOAA, National Ocean Service, Center for Coastal Fisheries and Habitat Research, \\ 101 Pivers Island Road, Beaufort, North Carolina 28516, USA
}

\begin{abstract}
Black band disease (BBD) of corals is characterized as a pathogenic microbial consortium composed of a wide variety of microorganisms. Together, many of these microorganisms contribute to an active sulfur cycle that produces anoxia and high levels of sulfide adjacent to the coral surface, conditions that are lethal to coral tissue. Sulfate-reducing bacteria, as sulfide producers, are an important component of the sulfur cycle and the black band community. Previous molecular survey studies have shown multiple Desulfovibrio species present in BBD but with limited consistency between bacterial species and infections. In this study we compared 16S rRNA gene sequences of sulfate-reducing bacteria selectively cultured from 6 BBD bands on 4 coral species, Diploria clivosa, D. strigosa, D. labyrinthiformes, and Siderastrea siderea, in the Florida Keys and Dominica. The 16S rRNA gene sequences were obtained through direct sequencing of PCR products or by cloning. A BLAST search revealed that 8 out of 10 cultures sequenced were highly homologous to Desulfovibrio sp. strain TBP-1, a strain originally isolated from marine sediment. Although the remaining 2 sequences were less homologous to Desulfovibrio sp. strain TBP-1, they did not match any other sulfate-reducing (or other) species in GenBank.
\end{abstract}

KEY WORDS: Coral disease - Black band disease - Sulfate-reducing bacteria • Desulfovibrio • Florida Keys · Dominica

Resale or republication not permitted without written consent of the publisher

\section{INTRODUCTION}

Black band disease (BBD) of scleractinian corals is considered to be an important factor in the decline and community restructuring of coral reefs (Rosenberg \& Loya 2004). This disease directly causes coral tissue lysis as it progresses over an infected coral colony, leading to either partial or complete death of the colony. Not only is coral tissue destroyed by the disease, but it has been shown that scleractinian coral recruitment onto the newly available substrate of exposed coral skeleton produced by BBD is negligible (Edmunds 1991, Bruckner \& Bruckner 1997, Kuta \& Richardson 1997), further reducing coral cover on reefs (Kuta \& Richardson 1996).

Characterized by a distinct black or dark red band, BBD is composed of a complex and distinct microbial consortium (Richardson et al. 1997, Bythell et al. 2002, Richardson 2004). The microbial consortium is dominated by cyanobacteria (Rützler \& Santavy 1983, Bythell et al. 2002, Cooney et al. 2002, Frias-Lopez et al. 2003, Richardson 2004), sulfide-oxidizing bacteria presumed to be Beggiatoa spp. (Ducklow \& Mitchell 1979, Viehman \& Richardson 2002), marine fungi (RamosFlores 1983), sulfate-reducing bacteria (SRB) including Desulfovibrio (Chet \& Mitchell 1975, Garrett \& Ducklow 1975, Cooney et al. 2002, Frias-Lopez et al. 2002), and many other heterotrophic microbes (Cooney et al. 2002, Frias-Lopez et al. 2002). Few members of the consortium have been cultured and no single or primary pathogen has been identified.

The complexity of the BBD microbial community has recently been explored using molecular techniques, 
which revealed a high degree of microbial diversity and variability among infections (Cooney et al. 2002, Frias-Lopez et al. 2002, 2003). However, the molecular techniques used in these studies, while providing a broad survey of the BBD microbial community, may not account for all bacteria present, particularly those present at low densities.

BBD has an active sulfur cycle similar to that found in microbial mats in extreme environments such as hotspring outflows and hypersaline ponds (Carlton \& Richardson 1995). Both BBD and such microbial mats contain anoxic and sulfide-rich microenvironments at depth in the mat. In the case of BBD, this zone is adjacent to the coral tissue, a condition which has been shown to cause coral tissue death (Richardson et al. 1997). In BBD, the source of this sulfide is biological, the result of dissimilatory sulfate reduction (Richardson 2004). SRB are ecologically significant in marine or hypersaline microbial mat environments where, as the dominant bacteria in the anaerobic zone, they may oxidize up to $50 \%$ of total organic carbon in support of sulfate respiration (Howarth \& Hobbie 1982, Jørgensen 1982). In seawater, the concentration of sulfate is abundant at approximately $28 \mathrm{mM}$ (Hansen 1993, Odom 1993), providing a sufficient sulfate supply for SRB to outcompete methanogens in an anaerobic microenvironment, and thus act as terminal oxidizers in the anaerobic degradation of organic matter to $\mathrm{CO}_{2}$ (Jørgensen \& Fenchel 1974). In a marine anoxic environment, the influx of organic matter can be a controlling factor for the rate of sulfate reduction (Jørgensen 1982).

Desulfovibrio spp. are commonly found in marine, estuarine and freshwater environments that are both anaerobic and reducing (Widdel \& Pfennig 1984). Although SRB carry out a potentially integral role in the etiology of BBD by producing toxic sulfide, characterization of SRB associated with BBD has been limited to date. SRB in BBD were first postulated to be Desulfovibrio spp. in the 1970s (Garrett \& Ducklow 1975). This was supported with fluorescence in situ hybridization analyses using SRB probes and confocal laser microscopy of the BBD microbial community (Schnell et al. 1996). Maximal growth of enrichment cultures of SRB from BBD on hydrogen and lactate, when compared with other electron donors, supported their identification as Desulfovibrio spp. (Schnell et al. 1996).

Two studies using culture-independent cloning of the 16S rRNA genes from BBD-associated microbial communities have shown a high diversity of bacteria within the disease consortium (Cooney et al. 2002, Frias-Lopez et al. 2002). These studies identified a variety of Desulfovibrio and other sulfate-reducing genera present in BBD infections. Most of the cloned strains were $<97.5 \%$ similar in sequence homology to the closest related GenBank deposit, and only partial gene sequences were used. Therefore, these results are subject to some sequence bias and are probably not indicative of a strict identification at the species level (Stackebrandt \& Goebel 1994). Bacterial strains with $>97.5 \%$ homology to Desulfovibrio salexigens and Desulfovibrio sp. strain TBP-1 were found in one survey of partial bacterial sequences cloned from 3 different BBD infections on different coral species in Curaçao (Frias-Lopez et al. 2002). No single Desulfovibrio species was common to the different infections.

SRB were also found on denuded coral skeleton behind BBD infections (Frias-Lopez et al. 2002). One clone, sequenced from the bacterial community on denuded coral skeleton, had $99 \%$ homology to Desulfovibrio sp. strain TBP-1. Although multiple Desulfovibrio species were found per sample from both BBD and denuded coral skeleton behind the band, no single Desulfovibrio species was found on more than 1 infection (Frias-Lopez et al. 2002). Additional clones were reported as $<97.5 \%$ homologous to $D$. zosterae and D. alaskensis, respectively. Clones identified as most closely matching other genera of SRB were also sequenced from denuded coral skeleton behind the band, but again at $<97.5 \%$ homology, thus not sufficient for a positive identification. These included Desulfofrigus oceanense strain Asv26, Desulfobotulus sp. strain BG14, Desulfocella halophila, Desulforhopalus singaporensis, Desulfofrigus fragile, and Desulfobacterium catecholicum (Frias-Lopez et al. 2002).

Perhaps the most obvious explanation for the variation in Desulfovibrio species among BBD infections is that SRB fill an ecophysiological niche rather than a species-specific niche in BBD. Given the bias inherent in the techniques used, more Desulfovibrio species may, in fact, have been present in the disease band than were cloned or sequenced; thus only a subsample of species present were detected in each sample. While theoretically providing a broad survey of the composition and variability of the BBD community, the polymerase chain reaction (PCR) based approach employed by these studies has an inherent bias for under-representation of bacteria that may be present at low densities. The question thus remains as to which, if any, microbial components of the disease are conserved between individual BBD infections and among various geographic areas.

The objective of this study was to culture and specifically select for Desulfovibrio spp. from different BBD infections on reefs in different regions of the Caribbean. The 16S rRNA gene sequences were used to compare the samples from this study to those found 
in previous BBD studies as well as to environmental SRB not associated with BBD.

\section{MATERIALS AND METHODS}

Field sampling. Active BBD was sampled in 2 locations in the Florida Keys-Picture Reef in Biscayne National Park (BNP) and Algae Reef in the Florida Keys National Marine Sanctuary (FKNMS) - plus 1 reef in Dominica: Tarou Point (Fig. 1). Six infected corals of 4 coral species, Diploria clivosa, D. labyrinthiformes, $D$. strigosa, and Siderastrea siderea, were sampled (Table 1). BBD samples were
Table 1. Sampling location and host coral species for black band disease (BBD) sulfate-reducing bacteria culturing and sequencing

\begin{tabular}{|c|c|c|}
\hline Sampling location & Coral species & $\begin{array}{c}\text { Culture } \\
\text { identification }\end{array}$ \\
\hline \multirow[t]{2}{*}{$\begin{array}{l}\text { Picture Reef, Biscayne } \\
\text { National Park, Florida }\end{array}$} & Diploria clivosa & $\begin{array}{l}\text { BBD-2 } \\
\text { BBD-3.1 }\end{array}$ \\
\hline & D. strigosa & BBD-6 \\
\hline \multirow[t]{3}{*}{ Dominica } & Siderastrea siderea 1 & $\begin{array}{l}\text { BBD-10 } \\
\text { BBD-11 }\end{array}$ \\
\hline & S. siderea 2 & $\begin{array}{l}\text { BBD-13.1 } \\
\text { BBD-15 }\end{array}$ \\
\hline & S. siderea 3 & $\begin{array}{l}\text { BBD-16 } \\
\text { BBD-19 }\end{array}$ \\
\hline $\begin{array}{l}\text { Algae Reef, Florida Keys } \\
\text { National Marine } \\
\text { Sanctuary, Florida }\end{array}$ & Diploria labyrinthiformis & BBD-22 \\
\hline \multicolumn{3}{|c|}{ aBBD-11.2 (not included here) was from the same culture as BBD-11 } \\
\hline
\end{tabular}

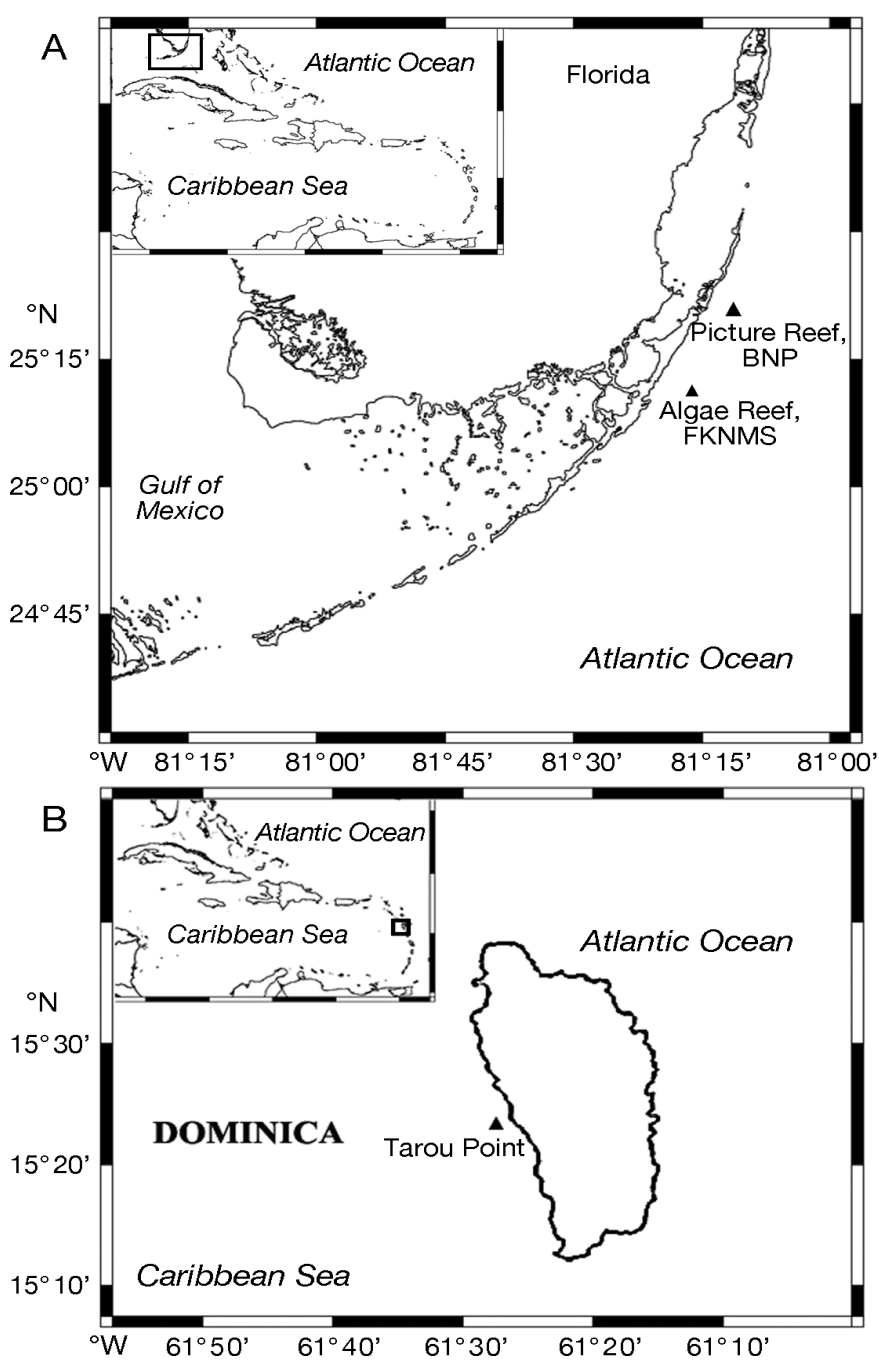

Fig. 1. Sampling sites (A) in the Florida Keys and (B) on the island of Dominica. BNP: Biscayne National Park; FKNMS: Florida Keys National Marine Sanctuary collected in situ on the reef by a SCUBA diver in July and September 2000. Sampling was conducted using sterile $10 \mathrm{ml}$ syringes to directly collect BBD. Upon return to the boat, samples in sealed syringes were maintained at ambient seawater temperature in coolers with low light, and then transported or shipped to the laboratory for immediate culture.

Enrichment and isolation of sulfate-reducers. The contents of the sampling syringes were inoculated directly into anoxic vials of Sulfate API Broth (Difco Laboratories) made with natural seawater. Prior to autoclaving and inoculation, air was removed from the sealed vials in alternating cycles of vacuum and $\mathrm{N}_{2}$ injected through a syringe apparatus. Media were always reduced prior to inoculation with either titanium NTA or $200 \mathrm{mM} \mathrm{H}_{2} \mathrm{~S}$ (final concentration) until a resazaurin indicator in the media indicated reducing (-Eh) conditions. Sulfate API media contains, per liter of distilled $\mathrm{H}_{2} \mathrm{O}$, bacto yeast extract $(1.0 \mathrm{~g})$, ascorbic acid $(0.1 \mathrm{~g})$, sodium lactate $(5.3 \mathrm{~g})$, magnesium sulfate $(0.2 \mathrm{~g})$, dipotassium phosphate $(0.01 \mathrm{~g})$, ferrous ammonium sulfate $(0.1 \mathrm{~g})$, and sodium chloride $(10.0 \mathrm{~g})$. Inoculated vials were visually monitored for an intense black FeS precipitate, indicative of bacterial sulfate reduction.

Standard microbiological techniques were used for culture of SRB from BBD. Subsampling of original inoculations and plating were carried out within a Coy anaerobic chamber (Coy Laboratory Products) containing approximately $90 \% \mathrm{~N}_{2}: 10 \% \mathrm{H}_{2}$ and trace amounts of $\mathrm{CO}_{2}$. Subsamples were inoculated into new vials of Sulfate API Broth. For isolation of individual colonies, agar plates were made with Sulfate API Broth, modified iron sulfate (Postgate 1984), or Postgate's B media (Postgate 1979), each using filtered (Whatman no. 1) or autoclaved seawater, Instant 
Ocean, or distilled water with addition of $\mathrm{NaCl}$. Single colonies producing a strong $\mathrm{FeS}$ precipitate were picked using a sterile glass pipette and transferred to Sulfate API Broth. Broth cultures that produced an FeS precipitate were re-inoculated onto modified iron sulfate agar plates and again subsampled into sealed anaerobic vials of Sulfate API Broth prior to removal from the anaerobic chamber.

DNA extraction and sequencing. Total DNA was extracted from each SRB culture using a Soil DNA Isolation Kit (MoBio Laboratories) and was PCR amplified on an MJ Research PTC 200 thermal cylinder. The PCR reaction consisted of $1 \times$ buffer; $2.5 \mathrm{mM} \mathrm{MgSO}{ }_{4} ; 0.25 \mu \mathrm{M}$ dNTPs; $0.5 \mu \mathrm{M}$ forward primer; $0.5 \mu \mathrm{M}$ reverse primer; $5 \mathrm{U} \mathrm{ul}^{-1}$ Tfl or Taq polymerase (Promega); $0.1 \%$ bovine serum albumin (BSA, fraction V) and DEPC $\mathrm{H}_{2} \mathrm{O}$ to $20 \mu \mathrm{l}$. To each reaction tube, $1 \mu \mathrm{l}$ DNA was added. Cycling parameters were: $94^{\circ} \mathrm{C}$ for $2 \mathrm{~min}^{3} 30$ cycles of: $94^{\circ} \mathrm{C}$ for $2 \mathrm{~min}, 55^{\circ} \mathrm{C}$ for $15 \mathrm{~s}$, and $72^{\circ} \mathrm{C}$ for $30 \mathrm{~s}$; followed by a final extension at $72^{\circ} \mathrm{C}$ for $10 \mathrm{~min}$. Universal bacterial polymerase chain reaction $(\mathrm{PCR})$ primers used were $\left[5^{\prime} \rightarrow 3^{\prime}\right]$ forward primer: FD1 (AGAGTTTGATCCTGGCTCAG) and reverse primer: RD1 (AAGGAGGTGATCCAGCC) (Weisburg et al. 1991), obtained from Gibco Life Technologies. Negative controls contained no DNA. Positive controls included cultures from this study that had previously been amplified with the given primer set, and a known Desulfovibrio strain, Desulfovibrio desulfuricans subspecies desulfuricans DSM 1924 (DSMZ - Deutsche Sammlung von Mikroorganismen und Zellkulturen). PCR products were visualized on a $1 \%$ agarose gel in TBE buffer stained with ethidium bromide. PCR fragments were purified for sequencing using Qiagen Qiaquick PCR Purification Kit (Qiagen). Three cultures that were partially sequenced from direct PCR were also cloned to avoid any bias in phylogenetic analysis from culture impurity. In each case the 16S rRNA gene PCR fragment from FD1 to RD1 was cloned using a TOPO TA cloning kit (Invitrogen) following the manufacturer's recommended protocols. The plasmid insert was sequenced with M13F and M13R primers (Invitrogen). Other primers used to sequence the PCR product included: $\left[5^{\prime} \rightarrow 3^{\prime}\right.$ ] FD1, 519R (G(G/T)ATTACCGCGGC (A/T)GCTG) (Lane et al. 1985), 926F (AAACTYAA AG(A/T)AATTGACGG) (Britschgi \& Fallon 1994), and RD1 (Weisburg et al. 1991). Optimal primers were designed using the OLIGO Primer Analysis Software (Molecular Biology Insights) and obtained from Gibco Life Technologies. These were $\left[5^{\prime} \rightarrow 3^{\prime}\right]$ 514F (CACTG GGCGTA AAGC), 1040R (CTCGTTGCGGGACTT), and 1056F (AAGTCCCGCAACGAG). Cycle sequencing was done on an MJ Research PTC 200 using the Big Dye terminator Cycle Sequencing kit version L (Perkin-Elmer) and run on an ABI Prism ${ }^{\mathrm{TM}} 377$ Automated DNA Sequencer (Perkin-Elmer).
Sequence analysis. The gene sequences obtained in this study from both cloning and direct-PCR were compared with those in the GenBank database using the basic local alignment search tool (BLAST) (www.ncbi.nlm.nih.gov). Only cloned sequences obtained in this study were used for phylogenic comparisons. Twenty-eight sequences of Desulfovibrio spp. and 8 sequences of delta proteobacterium were extracted from GenBank and used in phylogenetic comparisons. Seven sequences of SRB were also included for use as outgroups. Many of these sequences were chosen because they were homologous to sequences from this study or to sequences obtained in previous BBD molecular studies (Cooney et al. 2002, Frias-Lopez et al. 2002). Others were chosen as a random sample of complete or nearly complete Desulfovibrio spp. 16S rRNA gene sequences present in the GenBank database. In addition, 8 species of unidentified bacterial 16S rRNA genes from previous molecular studies of BBD and from bacteria found on denuded coral adjacent to the band were extracted from GenBank based on the published results of Cooney et al. (2002) and Frias-Lopez et al. (2002). All 16S rRNA gene sequences that were the most homologous to Desulfovibrio found in BBD infections in this study and in other BBD studies (Cooney et al. 2002, Frias-Lopez et al. 2002) were compared to Desulfovibrio sequences in GenBank.

Desulfovibrio spp. sequences were aligned on ClustalX (Thompson et al. 1997) with the cloned sequences obtained from this study. Alignments were visually checked on both ClustalX and MacClade (Maddison \& Maddison 2000). Analyses and tree construction were done using PAUP 4.0 (Swofford 1999). Heuristic search parameters were as follows: starting trees were obtained via neighbor-joining, sequences were added as-is, keeping best trees only, and the tree-bisection-recombination (TBR) branch swapping algorithm and steepest descent were used. Bootstrap support was obtained for 1000 replicates. Outgroups were assigned to be species other than Desulfo vibrio. These included Desulfofrigus fragile Desulfobotulus sp. BG14, Desulfuricans oceanense strain Asv26, Desulfocella halophila, Desulfobacterium catecholicum, and Desulforhopalus singaporensis. A neighbor-joining algorithm with a Jukes-Cantor distance measure was used.

Reference 16S rDNA sequences extracted from the GenBank database used in phylogenetic analysis follow: (1) Desulfovibrio spp.: Desulfovibrio. sp. D1 A318380, Desulfovibrio sp. D4 AF192155, Desulfovibrio sp. FD1 AJ251631, Desulfovibrio sp. strain KH2 X93147, Desulfovibrio sp. Met 82 AY062930, Desulfovibrio sp. PCP1 AF194417, Desulfovibrio sp. TBP-1 AF090830, Desulfovibrio sp. 'Bendigo A' AF131234, Desulfovibrio sp. strain STL 1 X99501, D. acrylicus U32578, D. aespoe- 
ensis X95230, D. africanus X99236, D. alaskensis Y11984, D. alcoholovorans AF053751, D. aminophilus AF067964, D. desulfuricans subsp. desulfuricans strain Essex 6 AF192153, D. desulfuricans subsp. desulfuricans strain MB AF192154, D. fairfieldensis U42221, D. gabonensis U31080, D. giganteus AF418170, D. halophilus U48243, D. indonensis Y09504, D. magneticus D43944, D. mexicoense AF227984, D. oryzae AF273083, D. profundus AF418172, D. salexigens M34401, D. vietnamensis X93994, D. zosterae Y18049. (2) Other bacterial species: CD12A12 AF441965, CD13B10 AF441876, delta proteobacterium RS15 AJ289743, delta proteobacterium RS64 AJ289756, SRB LZK1 AF216645, uncultured bacterium 128-3-12 AF473924, uncultured delta proteobacterium 128-11 AF473908, uncultured delta proteobacterium 128-12 AF473909, uncultured delta proteobacterium 34-35 AF473968, Desulfobotulus sp. BG14 U85470, Desolfocella halophila AF022936, Desulfobacterium catecholicum AJ237602, Desulfofrigus fragile AF099065, Desulfofrigus oceanense strain ASv26 AF099064, Desulforhopalus singaporensis AF118453

\section{RESULTS}

Successful enrichment cultures of SRB from BBD turned black after approximately 2 to $3 \mathrm{~d}$, indicating the precipitation of FeS. The best culture results were obtained using modified iron sulfate media in natural seawater. Although every BBD sample inoculated into enrichment media eventually indicated sulfatereduction, the limiting factor for this study was the appearance of single colonies for selection. Although a variety of BBD bacteria grew on the media, only single black colonies were selected on solid media for transferal to new media. Ten cultures were used in this study.

The 16S rRNA gene sequences were obtained from 3 cloned isolates, and 8 sequences were obtained directly from the PCR product from cultures. Of the 3 cloned 16S rRNA gene sequences, 2 nearly complete sequences were obtained. When aligned, both of these (BBD-3.1 from Biscayne National Park and BBD-11.2 from Dominica, cultured from Diploria clivosa and Siderastrea siderea, respectively; see Table 1) were $99 \%$ homologous to Desulfovibrio sp. TBP-1, and 98\% homologous to D. acrylicus and Desulfovibrio sp. PCP1 (Table 2). BBD-3.1 from this study was very closely related to 2 partial bacterial sequences cloned from BBD in a previous study (Frias-Lopez et al. 2002) and deposited as CD12A12 and CD13B10 (Fig. 2). BBD13.1 showed a lower degree of relatedness to the same group. The BLAST result for the 3rd cloned $633 \mathrm{bp}$ sequence (BBD-13.1 cultured from BBD on $S$. siderea in Dominica) was $96 \%$ homologous to Desulfovibrio sp.
TBP-1, and $95 \%$ homologous to D. acrylicus (Table 2). BBD-11.2, D. acrylicus, and Desulfovibrio sp. strain TBP-1 grouped separately, but with a low degree of support to each other (Fig. 2). The degree of separation between the cluster containing BBD-11.2, D. acrylicus, and Desulfovibrio sp. strain TBP-1 and that containing BBD-3.1, 13.1, CD12A12, and CD12B13 remains an unresolved polytomy. This is indicative of the lack of resolution within this genus when using the $16 \mathrm{~S}$ rRNA gene as a phylogenetic marker.

Sequencing directly from PCR products yielded 8 partial 16S rRNA gene sequences from SRB cultures of 6 different BBD infections from 4 different coral species. Six of these sequences, representing 5 out of 6 infections sampled, revealed $>97 \%$ homology in a BLAST search to 2 uncultured delta proteobacterium clones, CD13B10 and CD12A12, both cloned from BBD on Montastraea cavernosa in Curaçao by Frias-Lopez et al. (2002). Only 1 BBD sample, BBD-15 cultured from BBD on Siderastrea siderea in Dominica, did not yield a SRB with a high degree of homology $(<97.5 \%)$ to Desulfovibrio spp. in GenBank. No relationship was supported between infected coral species and BBDSRB species cultured. The partial sequences obtained in this study from direct PCR were not used in phylogenetic analysis to avoid compounding bias from trying to extrapolate relatedness of short sequences to longer or more complete sequences.

\section{DISCUSSION}

The use of culture techniques to assess microorganisms in natural samples vastly underestimates microbial community diversity (Furhman \& Campbell 1998). Possibly as few as $\leq 1 \%$ of bacteria present in nature can be cultured (Hicks et al. 1992). In this study, selective culturing techniques were used to specifically enrich for BBD SRB with similar growth requirements (i.e. members of the genus Desulfovibrio) from different BBD infections. Although this approach may have artificially selected for Desulfovibrio spp. found at background levels in BBD infections, perhaps at low levels not necessarily detectable by molecular survey techniques, we believe that this approach addresses the hypothesis that individual Desulfovibrio spp. specifically fill an ecological niche within BBD in different infections. Additional species of SRB may also be important in the BBD microbial consortium, but were not assessed in this study. We found the presence of bacterial species with a high degree of homology to the same Desulfovibrio species, cultured from both Florida Keys samples and from Dominica samples as well as sequenced from a sample in Curaçao (Frias-Lopez et al. 2002). Thus our results suggest that this species may be com- 
Table 2. 16S rRNA gene sequence homologies from BBD sulfate-reducing bacteria. Both full and partial sequences were used

\begin{tabular}{|c|c|c|c|c|c|}
\hline $\begin{array}{l}\text { Sample } \\
\text { identification }\end{array}$ & Primers & $\begin{array}{l}\text { No. } \\
\text { of bases }\end{array}$ & $\begin{array}{c}\text { GenBank } \\
\text { accession no. }\end{array}$ & $\%$ homology & $\begin{array}{l}\text { Source of GenBank sequence } \\
\text { with highest homology }\end{array}$ \\
\hline BBD-2 & $\begin{array}{l}\text { FD1 } \\
\text { RD1 }\end{array}$ & $\begin{array}{l}487 \\
358\end{array}$ & $\begin{array}{l}\text { AY907525 } \\
\text { AY907526 }\end{array}$ & $\begin{array}{c}97 \\
97 \\
96-97\end{array}$ & $\begin{array}{l}\text { Uncultured delta proteobacterium clone CD13B10 } \\
\text { Uncultured delta proteobacterium clone CD12A12 } \\
\text { Desulfovibrio acrylicus }\end{array}$ \\
\hline BBD- $3.1^{\mathrm{a}}$ & Various & 1476 & AY750147 & $\begin{array}{l}99 \\
98\end{array}$ & $\begin{array}{l}\text { Desulfovibrio sp. strain TBP-1 } \\
\text { D. acrylicus }\end{array}$ \\
\hline BBD-6 & $\begin{array}{l}\text { FD1 } \\
\text { RD1 }\end{array}$ & $\begin{array}{l}486 \\
432\end{array}$ & $\begin{array}{l}\text { AY907527 } \\
\text { DQ020004 }\end{array}$ & $\begin{array}{l}98-99 \\
97-99 \\
97-99 \\
97-99\end{array}$ & $\begin{array}{l}\text { Uncultured delta proteobacterium clone CD13B } 10^{\mathrm{b}} \\
\text { Uncultured delta proteobacterium clone CD12A } 12^{\mathrm{b}} \\
\text { Desulfovibrio sp. strain TBP-1 } \\
\text { D. acrylicus }\end{array}$ \\
\hline BBD-10 & $\begin{array}{l}\text { FD1 } \\
\text { RD1 }\end{array}$ & $\begin{array}{l}211 \\
407\end{array}$ & $\begin{array}{l}\text { AY907528 } \\
\text { AY907529 }\end{array}$ & $\begin{array}{c}99 \\
99 \\
96-99 \\
95-98\end{array}$ & $\begin{array}{l}\text { Uncultured delta proteobacterium clone CD13B10 } \\
\text { Uncultured delta proteobacterium clone CD12A12 } \\
\text { Desulfovibrio sp. strain TBP-1 } \\
\text { D. acrylicus }\end{array}$ \\
\hline BBD-11 & $\begin{array}{l}\text { FD1 } \\
519 R\end{array}$ & $\begin{array}{l}560 \\
421\end{array}$ & AY907530 & $\begin{array}{l}96-99 \\
95-98\end{array}$ & $\begin{array}{l}\text { Desulfovibrio sp. strain TBP-1 } \\
\text { D. acrylicus }\end{array}$ \\
\hline BBD-11. $2^{\mathrm{a}}$ & Various & 1536 & AY750148 & $\begin{array}{l}99 \\
98\end{array}$ & $\begin{array}{l}\text { Desulfovibrio sp. TBP-1 } \\
\text { D. acrylicus }\end{array}$ \\
\hline BBD-13.1 ${ }^{\mathrm{a}}$ & $\begin{array}{l}\text { M13 } \\
\text { FD1 }\end{array}$ & 633 & AY750149 & $\begin{array}{l}96 \\
95\end{array}$ & $\begin{array}{l}\text { Desulfovibrio sp. TBP-1 } \\
\text { D. acrylicus }\end{array}$ \\
\hline BBD-15 & $519 \mathrm{R}$ & 367 & AY907531 & $\begin{array}{l}94 \\
94 \\
94\end{array}$ & $\begin{array}{l}\text { Delta proteobacterium RS64 } \\
\text { D. acrylicus } \\
\text { Desulfovibrio sp. strain TBP-1 }\end{array}$ \\
\hline BBD-16 & $\begin{array}{l}\text { FD1 } \\
\text { RD1 } \\
926 \mathrm{~F}\end{array}$ & $\begin{array}{l}471 \\
533 \\
293\end{array}$ & $\begin{array}{l}\text { AY907532 } \\
\text { AY907533 } \\
\text { AY907534 }\end{array}$ & $\begin{array}{l}98-99 \\
98-99 \\
97-99 \\
97-99\end{array}$ & $\begin{array}{l}\text { Uncultured delta proteobacterium clone CD13B10 } \\
\text { Uncultured delta proteobacterium clone CD12A12 } \\
\text { Desulfovibrio sp. strain TBP-1 } \\
\text { D. acrylicus }\end{array}$ \\
\hline BBD-19 & RD1 & 664 & AY907535 & $\begin{array}{l}98 \\
98 \\
97 \\
97\end{array}$ & $\begin{array}{l}\text { Uncultured delta proteobacterium clone CD13B } 10^{\mathrm{b}} \\
\text { Uncultured delta proteobacterium clone CD12A12 } \\
\text { Desulfovibrio sp. strain TBP-1 } \\
\text { D. acrylicus }\end{array}$ \\
\hline BBD-22 & FD1 & 241 & AY907536 & $\begin{array}{l}98 \\
98 \\
98 \\
98\end{array}$ & $\begin{array}{l}\text { Uncultured delta proteobacterium clone CD13B10 } \\
\text { Uncultured delta proteobacterium clone CD12A12 } \\
\text { Desulfovibrio sp. strain TBP-1 } \\
\text { D. acrylicus }\end{array}$ \\
\hline
\end{tabular}

mon to the BBD microbial community and may play the role of a required BBD consortium member.

The Desulfovibrio cultures obtained in this study were presumably able to outcompete other SRB present because of the provision of much higher levels of lactate as opposed to yeast extract. Use of lactate as a preferred carbon source is characteristic of the genus Desulfovibrio. Although the yeast extract present in the media is an additional or alternative carbon source, it was present in a much lower amount and thus would not confer a selective advantage for growth of additional BBD sulfate reducing genera that may be present. Presumably, a wide variety of carbon compounds are produced during the lysis of coral tissue that may potentially be used by representatives of the different genera of sulfate-reducers.

In this study we obtained 10 cultures of SRB from 6 different BBD infections, from 3 different reefs in differ- ent areas of the wider Caribbean. All but 2 of the cultures had 16S rRNA gene sequences (partial to almost complete) with $>97.5 \%$ homologies to Desulfovibrio sp. TBP-1 and D. acrylicus (Table 2). Six of these sequences were also highly homologous to the uncultured delta proteobacterium clones CD13B10 and CD12A12, both obtained from BBD (Frias-Lopez et al. 2002). Although 2 of our 10 sequences, both from the same Siderastrea siderea infection in Dominica, were most homologous to Desulfovibrio sp. TBP-1 and D. acrylicus, they had $<97.5 \%$ homology (Stackebrandt \& Goebel 1994).

Only partial sequences were obtained from direct PCR sequencing from 8 of our 10 cultures, and in 1 of the 3 clones analyzed in this study. Therefore, direct comparisons of our results to those of the earlier studies (Cooney et al. 2002, Frias-Lopez et al. 2002) are complicated by the fact that the location of the 


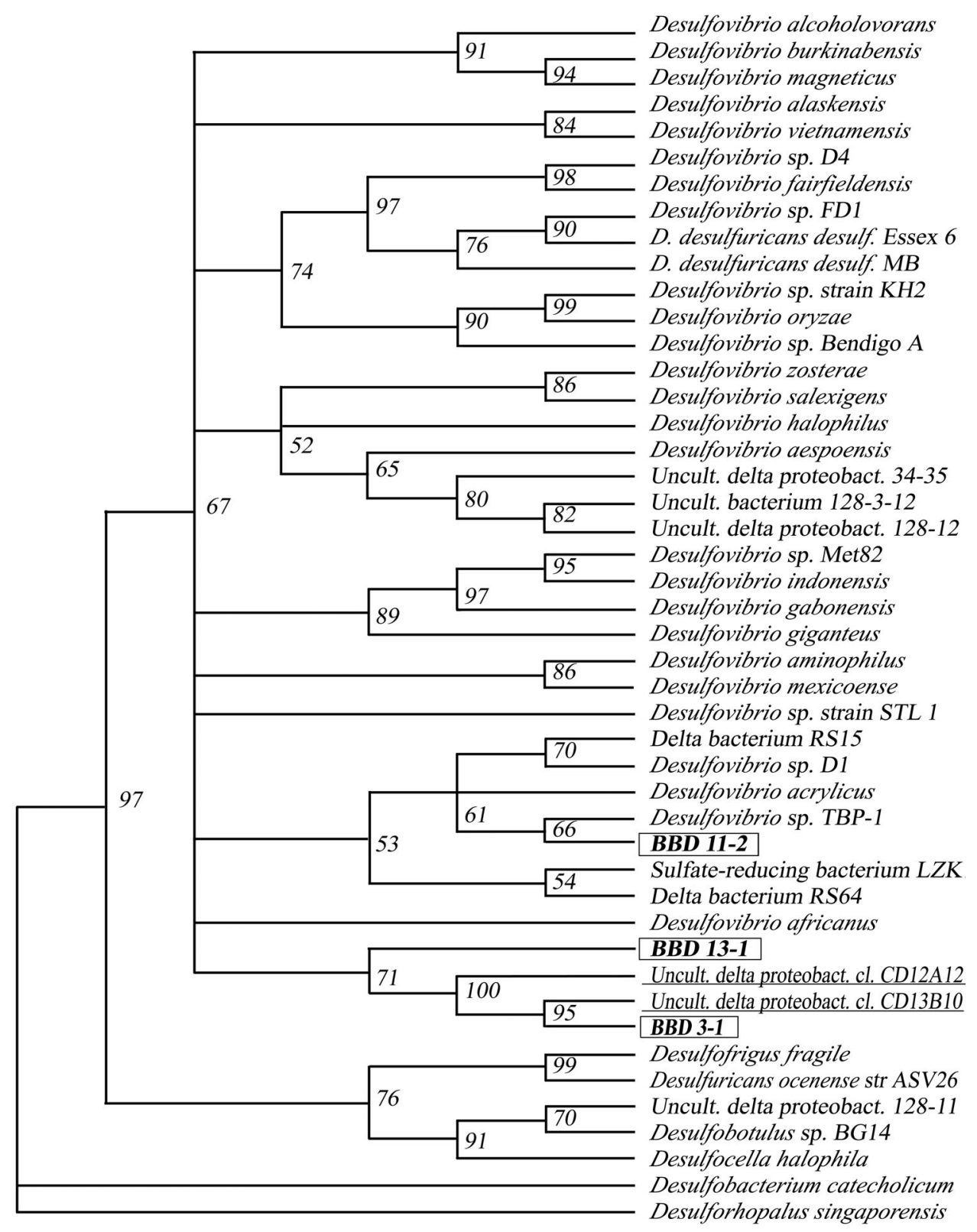

Fig. 2. Phylogenetic tree of Desulfovibrio spp. sequenced in this study, Desulfovibrio spp. from the environment (GenBank), and Desulfovibrio and other sulfate-reducing bacteria (SRB) cloned from black band disease (BBD) infections in other studies, from 1000 bootstrap replicates with Jukes-Cantor distance measure. Only bootstrap support values above 50\% are presented. SRB sequences of clones from this study are in boxes. SRB sequences of clones from Frias-Lopez et al. (2002) are underlined

sequences of the 16S rRNA gene may not overlap with the exact sequence locations in each study. For example, the SRB BBD-15 (Table 2) was sequenced using primer 519R (thus sequencing more toward the 5' end of the gene), and therefore was not comparable to the sequences of the 3 ' end from the uncultured delta proteobacteria (CD12A12 and CD13B10) cloned from BBD by Frias-Lopez et al. (2002). This lack of overlap is the reason why partial sequences obtained from direct PCR were not included in phylogenetic analysis. Therefore, even though all 3 of these sequences had a high degree of homology to Desulfovibrio sp. TBP-1 and $D$. acrylicus we cannot conclude that each partial sequence represents the same species because the sequences were located in different regions of the $16 \mathrm{~S}$ rRNA genes.

An alternative aspect of using partial gene sequence data to study microbial communities is the problem of ubiquitous species that may be routinely identified, but falsely interpreted as important constituents in the niche being studied. For example, both Desulfovibrio sp. TBP-1 and D. acrylicus that were originally 
deposited in GenBank came from marine or estuarine sediment samples (van der Maarel et al. 1996, Boyle et al. 1999) and, therefore, may be ubiquitous in marine sediments. Frias-Lopez et al. (2002) found Desulfovibrio sp. TBP-1 in 1 out of 3 samples of the sediment on the denuded coral surface behind the disease band. An additional problem can arise when the partial sequences surveyed are highly conserved within the genus and/or species. This can lead to misinterpretation of the true identity of the species when the genetic marker of choice (i.e. 16S rRNA) is not completely sequenced. Therefore, results from partial sequences must be cautiously interpreted when assigning niche and/or community status to such data.

Desulfovibrio sp. TBP-1 and D. acrylicus share $98.9 \%$ sequence homology to each other, and both were implicated as important, and perhaps common, members of the BBD microbial consortium. However, these 2 species have different physiological characteristics. D. acrylicus, unlike Desulfovibrio sp. strain TBP-1, can reduce acrylate but cannot grow on lactate and acrylate with $>4 \% \mathrm{NaCl}$ in growth media. Desulfovibrio sp. TBP-1, unlike D. acrylicus, can also grow on fumarate and sulfate (Boyle et al. 1999). This illustrates another limitation of the exclusive use of $16 \mathrm{~S}$ rRNA gene sequences for identification and analysis of microbial communities in that when more than one species is implicated as present, knowledge of the physiological properities of known species should be considered in interpreting the molecular data. Within this study, clones and PCR products of samples were analyzed in terms of homology to only the 16S rRNA gene. Sequence homology to functional or physiologically related genes would provide more information to more accurately identify species present. The lack of resolution at so many branches in the phylogenetic tree further indicates the lack of resolution of the 16S rRNA gene for this genus. However, the 16S rRNA gene was targeted to allow comparison of our results to other studies of BBD SRB.

Other factors to consider in these types of studies, in particular when different research groups find significant differences in species homologies and low levels of bootstrap support, could be based on the inherent biases of the phylogenetic methods used. The JukesCantor distance analysis has the underlying assumption that all bases are equally likely to vary at the same rate (Gillespie 1986). Given this, phylogenetic bootstrap support and evolutionary branch lengths are likely overestimates of actual values. Parsimony-based methods also underestimate rate variation (Yang 1996). None of the phylogenetic analyses of Desulfovibrio spp. (Devereux et al. 1990, Rooney-Varga et al. 1998, Castro et al. 2000) appear to have taken into account the rate variation of specific base sites with regard to rRNA structure, even though such variation considerably influences evolution (Yang 1996).

In this study, only limited phylogenetic clustering was found between non-BBD related Desulfovibrio species and those found in (or highly homologous to those found in) BBD. In addition, no relationships were shown between Desulfovibrio species from BBD and the species of coral infected. Two Desulfovibrio spp. cultured in this study, BBD-3.1 and BBD-13.1 (Fig. 2), were closely related to 2 clones from a BBD infection on a Montastraea cavernosa in Curaçao (Frias-Lopez et al. 2002). However, this group clustered separately (although via an unresolved polytomy) from the cluster including $D$. acrylicus, Desulfovibrio sp. D1, Desulfovibrio sp. strain TBP-1, BBD-11.2 from this study, and the non-BBD delta proteobacterium RS15, despite high degrees of sequence homology.

In summary, we found evidence that BBD may contain specific SRB species common to BBD infections both on different coral hosts and in different regions of the wider Caribbean. While our findings support the hypothesis that SRB may be filling an ecological niche in $\mathrm{BBD}$, and that there is no coral species specificity, our results can also be interpreted as evidence that there is in fact microbial species specificity. We believe that additional physiological studies aimed at culturing specific functional groups, genera, or even species, supplemented by molecular studies targeting functional gene expression, must be carried out to support BBD microbial community assessment using PCR. Another promising approach is use of real time PCR to quantify the number of microbial species present. Only in this way can we determine which microbial species are functionally important in the natural environment.

Acknowledgements. We thank J. Borger, D. Diresta, R. Curry, and $\mathrm{M}$. Walker for sample assistance. We also thank Biscayne National Park (BNP) and the Florida Keys National Marine Sanctuary (FKNMS) for research vessel support. Sample collection in the FKNMS was carried out under National Marine Sanctuary Permit FKNMS-2000-056 and in BNP was included under National Park Service Permit BISC 00-032. We thank E. Weil, G. Smith, D. Gil-Agudelo, G. Piniak and 3 anonymous reviewers for helpful comments on the manuscript. This research was funded by an EPA STAR graduate fellowship (U-91562001 to S.V.). Funding from NIH (NIH/NIGMS SO6GM8205 to L.L.R. and D.K.M.) and NSF (NSF ADVANCE 0340695 to D.K.M.) assisted in presenting and producing this document. This is contribution 104 from the Tropical Biology Program at Florida International University.

\section{LITERATURE CITED}

Boyle AW, Phelps CD, Young LY (1999) Isolation from estuarine sediments of a Desulfovibrio strain which can grow on lactate coupled to the reductive dehalogenation of 2,4,6-tribromophenol. Appl Environ Microbiol 65:1133-1140 
Britschgi TB, Fallon RD (1994) PCR amplification of mixed 16S rRNA genes from an anaerobic, cyanide-degrading consortium. FEMS Microbiol Ecol 13:225-231

Bruckner AW, Bruckner R (1997) The persistence of black-band disease in Jamaica: impact on community structure. Proc 8th Int Coral Reef Symp 1:601-606

Bythell JC, Barer MR, Cooney RP, Guest JR, O'Donnell AG, Pantos O, Le Tissier MDA (2002) Histopathological methods for the investigation of microbial communities associated with disease lesions in reef corals. Lett Appl Microbiol 34: 359-364

Carlton RG, Richardson LL (1995) Oxygen and sulfide dynamics in a horizontally migrating cyanobacterial mat: black band disease of corals. FEMS Microbiol Ecol 18:155-162

Castro H, Williams N, Ogram A (2000) Phylogeny of sulfate-reducing bacteria. FEMS Microbiol Ecol 31:1-9

Chet I, Mitchell R (1975) Bacterial attack of corals in polluted seawater. Microb Ecol 2:227-233

Cooney RP, Pantos O, Le Tissier MDA, Barer MR, O'Donnell AG, Bythell JC (2002) Characterization of the bacterial consortium associated with black band disease in coral using molecular microbiological techniques. Environ Microbiol 4: 401-413

Devereux R, He SH, Doyle CL, Orkland S, Stahl SA, LeGall J, Whitman WB (1990) Diversity and origin of Desulfovibrio species: phylogenetic definition of a family. J Bacteriol 172: 3609-3619

Ducklow HW, Mitchell R (1979) Observations on naturally and artificially diseased tropical corals: a scanning electron microscope study. Microb Ecol 5:215-223

Edmunds PJ (1991) Extent and effect of black band disease on a Caribbean reef. Coral Reefs 10:161-165

Frias-Lopez J, Zerkle AL, Bonheyo GT, Fouke BW (2002) Partitioning of bacterial communities between seawater and healthy, black band diseased, and dead coral surfaces. Appl Environ Microbiol 68:2214-2228

Frias-Lopez J, Bonheyo GT, Jin Q, Fouke BW (2003) Cyanobacteria associated with coral black band disease in Caribbean and Indo-Pacific reefs. Appl Environ Microbiol 69:2409-2413

Furhman JA, Campbell L (1998) Marine ecology: microbial diversity. Nature 393:410-411

Garrett P, Ducklow H (1975) Coral diseases in Bermuda. Nature 253:349-350

Gillespie JH. (1986) Rates of molecular evolution. Annu Rev Ecol Syst 17:637-655

Hansen TA (1993) Carbon metabolism of sulfate-reducing bacteria. In: Odom JM, Singleton R (eds) The sulfate-reducing bacteria: contemporary perspectives. Springer, New York, p 21-40

Hicks RE, Ammann RI, Stahl DA (1992) Dual staining of natural bacterioplankton with 4', 6-diamidino-2-phenylindole and fluorescent oligonucleotide probes targeting kingdom-level 16S rRNA sequences. Appl Environ Microbiol 58: $2158-2163$

Howarth RW, Hobbie JE (1982) The regulation of decomposition and heterotrophic microbial activity in salt marsh soils: a review. In: Kennedy VS (ed) Estuarine comparisons. Academic Press, New York, p 103-127

Jørgensen BB (1982) Ecology of the bacteria of the sulphur cycle with special reference to anoxic-oxic interface environments. Phil Trans R Soc Lond B Biol Sci 298:548-561

Jørgensen BB, Fenchel T (1974) The sulfur cycle of a marine sediment model system. Mar Biol 24:189-201

Kuta KG, Richardson LL (1996) Abundance and distribution of black band disease on coral reefs in the northern Florida Keys. Coral Reefs 15:219-223
Kuta KG, Richardson LL (1997) Black band disease and the fate of diseased coral colonies in the Florida Keys. Proc 8th Int Coral Reef Symp 1:575-578

Lane DJ, Pace B, Olsen GJ, Stahl DA, Sogin ML, Pace NR (1985) Rapid determination of 16S ribosomal RNA sequences for phylogenetic analyses. Proc Natl Acad Sci USA 82: 6955-6959

Maddison D, Maddison W (2000) MacClade 4. Analysis of phylogeny and character evolution. Sinauer, Sunderland, MA

Odom J (1993) Industrial and environmental activities of sulfatereducing bacteria. In: Odom JM, Singleton R (eds) The sulfate-reducing bacteria: contemporary perspectives. Springer, New York, p189-210

Postgate JR (1979) The sulphate-reducing bacteria. Cambridge University Press, Cambridge

Postgate JR (1984) The sulphate-reducing bacteria, 2nd edn. Cambridge University Press, Cambridge

Ramos-Flores T (1983) Lower marine fungus associated with black line disease in star corals (Montastraea annularis E. \& S.). Biol Bull 165:429-435

Richardson LL (2004) Black band disease. In: Rosenberg E, Loya Y (eds) Coral health and disease. Springer, Berlin, p 325-336

Richardson LL, Kuta KG, Schnell S, Carlton RG (1997) Ecology of the black band disease microbial consortium. Proc 8th Int Coral Reef Symp 1:597-600

Rooney-Varga JN, Genthner BRS, Devereux R, Willis SG, Friedman SD, Hines ME (1998) Phylogenetic and physiological diversity of sulphate-reducing bacteria isolated from a salt marsh sediment. Syst Appl Microbiol 21: $557-568$

Rosenberg E, Loya Y (2004) Coral health and disease. Springer, Berlin

Rützler K, Santavy DL (1983) The black band disease of Atlantic reef corals I. Description of the cyanophyte pathogen. PSZN I: Mar Ecol 4:301-319

Schnell S, Assmus B, Richardson LL (1996) Role of sulfate-reducing bacteria in the black band disease of corals. Annual Meeting of the VAAM (Vereinigung für Allgemeine und Angewandte Mikrobiologie) and $\mathrm{GBCH}$ (Gesellschaft für Biologische Chemie). Biospektrum 116

Stackebrandt E, Goebel BM (1994) A place for DNA-DNA reassociation and $16 \mathrm{~S}$ ribosomal-RNA sequence analysis in the present species definition in bacteriology. Int J Syst Bacteriol 44:846-849

Swofford DL (1999) PAUP: phylogenetic analysis using parsimony. Version 4.0. Sinauer, Sunderland, MA

Thompson J, Gibson T, Plewniak F, Jeanmougin F, Higgins D (1997) The ClustalX windows interface: flexible strategies for multiple sequence alignment aided by quality analysis tools. Nucleic Acids Res 24:4876-4882

van der Maarel MJEC, van Bergeijk S, van Werkhoven AF, Laverman AM, Meijer WG, Stam WT, Hansen TA (1996) Cleavage of dimethylsulfoniopropionate and reduction of acrylate by Desulfovibrio acrylicus sp. nov. Arch Microbiol 166:109-115

Viehman TS, Richardson LL (2002) Motility patterns of Beggiatoa and Phormidium corallyticum in black band disease. Proc 9th Int Coral Reef Symp 2:1251-1255

Weisburg WG, Barns SM, Pelletier DA, Lane DJ (1991) 16S ribosomal DNA amplification for phylogenetic study. J Bacteriol 173:697-703

Widdel F, Pfennig N (1984) Dissimilatory sulfate- or sulfurreducing bacteria. In: Krieg NR, Holt JG (eds) Bergey's manual of systematic bacteriology. Williams \& Wilkins, Baltimore, p 663-679

Yang Z (1996) Among-site rate variation and its impact on phylogenetic analyses. Trends Ecol Evol 11:367-372 